\title{
First Record of Rhopalosiphum maidis (Fitch) (Homoptera: Aphididae) in Slovakia
}

\author{
L'. CAGÁŇ and M. ŠTALMACHOVÁ \\ Department of Plant Protection, Slovak Agricultural University, \\ 94976 Nitra, Slovakia
}

\begin{abstract}
During the autumn of 1999, an outbreak of Rhopalosiphum maidis (Fitch) was observed on barley volunteers at locality Nitra-Malanta $\left(48^{\circ} 19^{\prime} \mathrm{N}, 18^{\circ} 09^{\prime} \mathrm{E}\right)$ in Slovakia. Barley plantation arose from dropped grain of spring barley harvested on July 20, 1999. The soil was not cultivated after the harvest. During the observation, in October, nearly $80 \%$ of tillers were in growth stage of heading and nearly $20 \%$ of tillers were in growth stage of booting. The abundance of $R$. maidis reached 61.13 and 67.37 individuals per main and lateral tiller respectively. $R$. maidis was not observed on maize fields in the vicinity of the infested barley plantation. The highest percentage of populations constituted larvae and nymphs. Alate females formed $6.7 \%$ of the $R$. maidis population. From 2116 aphids observed on 30 main tillers 97 (4.58\%) and from 2283 aphids observed on 30 lateral tillers $153(6.70 \%)$ were infected by entomophthoralean fungi Entomophthora planchoniana Cornu or Erynia neoaphidis Remaudière et Hennebert.
\end{abstract}

Keywords: Rhopalosiphum maidis, Entomophthora planchoniana, Erynia neoaphidis.

Rhopalosiphum maidis (Fitch) is a common aphid on maize in many countries of the world. It is usual on maize in the USA (Irwin and Thresh, 1988), south European countries like Portugal (De-Gouveia, 1984), France (Breniaux et al., 1976), or Spain (Pons et al., 1989; Fereres et al., 1990) and in Africa (Darwish and Ali, 1991). R. maidis was common on maize in Bulgaria (Grigorov, 1982) and Turkey (Bremer and Raatikainen, 1975).

Because $R$. maidis develops only partenogenetically, and it is not able to overwinter by eggs (Müller, 1961), it does not occur in colder regions of Europe. Its distribution in Europe is limited from $40^{\circ} \mathrm{N}$ to $45^{\circ} \mathrm{N}$, accidentally up to $50^{\circ} \mathrm{N}$ (Knechtel and Manolache, 1944). In 1960, R. maidis was recorded for the first time in eastern Germany (Müller and Freitag, 1960). In England, R. maidis was first found in 1955 (Stroyan, 1955). R. maidis was also observed in Sweden (Ossiannilsson, 1959), Poland (Kania, 1962), Hungary (Milinkó et al., 1983; Mészáros et al., 1984) and Romania (Knechtel and Manolache, 1944; Manolache et al., 1968). Three main aphid species were found on maize at Rennes (northwest of France). The fourth species, $R$. maidis, was observed only once (Henry and Dedryver, 1989).

From 1997-1999, the population dynamics of aphids on maize plants was studied at Nitra-Malanta $\left(48^{\circ} 19^{\prime} \mathrm{N}, 18^{\circ} 09^{\prime} \mathrm{E}\right)$ in Slovakia. The aim of the study was to explain how entomophthoralean fungi influence cereal aphid populations on maize. The results from the years 1997 and 1998 have already been published (Štalmachová and Cagáň, 1999). In October 1999, a new aphid species, $R$. maidis, was found on barley volunteers near the Nitra-Malanta locality.

Up to now, there has been no information about the occurrence of $R$. maidis in Slovakia. In this paper, circumstances surrounding the appearance of $R$. maidis in Slovakia are discussed. 


\section{Materials and Methods}

The field with barley volunteers, where $R$. maidis was found in 1999, was situated at Nitra-Malanta locality at altitude of $230 \mathrm{~m}, 1 \mathrm{~km}$ east of the experimental base of the Slovak Agricultural University in Nitra.

Barley volunteers rose from lost grains of spring barley harvested on July 20, 1999. The soil was not cultivated after the harvest. During the observation, in October, nearly $80 \%$ of barley tillers were in the growth stage of heading and nearly $20 \%$ of tillers were in growth stage of booting

At the barley volunteer field (variety Sladko, 0.5 hectare) where $R$. maidis was found, 30 plants were analysed for the occurrence of aphids. The main tiller and the first lateral tiller were taken for analysis from each plant. The alatae and apterous individuals of each aphid species were counted. The number of aphids infected by entomophthoralean fungi and parasitized aphids was recorded as well. The same procedure was conducted on 60 maize plants on maize field about $1 \mathrm{~km}$ distant from examined barley field.

Additional five maize fields were examined to find out if $R$. maidis occurs there, too.

To show if the population of $R$. maidis can well develop in Slovakia, the demographic structure of aphid population was investigated. Although, the demographic structure of other species found on barley volunteer field was made for comparison. Ten barley plants infested by aphids were put into the freezer for 5 hours. Then, aphids were collected from the plants by shaking, put in $70 \%$ alcohol and counted. Aphids of each species were sorted out into four groups; larvae, nymphs, apterous females and alate females.

The spectrum of entomopathogens infecting aphids on barley volunteers was identified by using the method of Papierok (1989). Each infected aphid was placed to a piece of damp cellulose inside a small Petri dish lid (diameter $35 \mathrm{~mm}$ ). Then, the Petri dish lid was placed over a microscope slide. The damp conditions initiated the sporulation of fungus and the conidia were collected on microscope slide. After, the conidia were mounted in lactophenol-cotton blue. The fungal species was identified from the shape and size of conidia.

\section{Results and Discussion}

In 1999, the population dynamics of aphids on maize included two peaks. The first peak occurred during the second half of June and Metopolophium dirhodum (Walker) was the dominant species. The second peak was recorded at the beginning of September but aphid populations were much less numerous than in June. M. dirhodum was the dominant species again and $14 \%$ of the aphid population constituted $R$. padi.

The same aphid species were found at 5 other maize fields surveyed at different localities 15 kilometres around the locality Nitra-Malanta. $R$. maidis was found on maize plants neither during the growing season, nor in autumn.

This species was not usual on maize at colder localities. In Hampshire, England, on the maize crop, $M$. dirhodum and $R$. padi were found at densities that exceeded those 
found on small-grain cereals and grasses at the same time of year. Sitobion avenae (F.), and Macrosiphon euphorbiae (Thomas) were found at relatively low densities, and $R$. maidis and Macrosiphon festucae (Theo.) were observed rarely (Hand and Carrillo, 1982). On the other hand, four aphid species, including $R$. maidis, $R$. padi, S. avenae and M. dirhodum were observed on barley plants during October 1999 in Slovakia. Table 1 shows the numbers of individuals from each species. The average number of aphids per main and lateral tiller was 61.13 and 67.37 (R. maidis), 7.50 and 7.43 (R. padi), 1.67 and 1.30 ( $S$. avenae), or 0.23 and 0.10 ( $M$. dirhodum), respectively. The difference between numbers of aphids on the main and lateral tiller was insignificant (analysis of variance, Tukey test). The table shows that $R$. maidis had higher capacity to develop on barley plant than $R$. padi. S. avenae and M. dirhodum do not seem have any importance in autumnal damage of barley.

Table 1

Number of aphids $(\mathrm{x} \pm \mathrm{s})$ per main tiller and per lateral tiller of barley plant on October 13, 1999 (variety Sladko) and maize plants on September 30.

Locality Nitra-Malanta $\left(48^{\circ} 19^{\prime} \mathrm{N}, 18^{\circ} 09^{\prime} \mathrm{E}\right)$. Altitude $230 \mathrm{~m}$

\begin{tabular}{lcccccc}
\hline & \multicolumn{2}{c}{ barley volunteers } & \multicolumn{2}{c}{ maize } \\
& \multicolumn{2}{c}{ main tiller } & \multicolumn{2}{c}{ lateral tiller } & & \\
\cline { 2 - 7 } & alatae & apterous & alatae & apterous & alatae & apterous \\
\hline \multirow{2}{*}{ Rhopalosiphum maidis } & $1.3 \pm 1.92$ & $59.83 \pm 59.80$ & $0.6 \pm 0.95$ & $66.7 \pm 48.58$ & $0 \pm 0$ & $0 \pm 0$ \\
Rhopalosiphum padi & $0.1 \pm 0.40$ & $7.40 \pm 10.47$ & $0.03 \pm 0.18$ & $7.40 \pm 6.72$ & $0.03 \pm 0.18$ & $0.13 \pm 0.78$ \\
Sitobion avenae & $0 \pm 0$ & $1.67 \pm 3.94$ & $0.03 \pm 0.18$ & $1.27 \pm 3.30$ & $0 \pm 0$ & $0 \pm 0$ \\
Metopolophium dirhodum & $0 \pm 0$ & $0.23 \pm 1.26$ & $0 \pm 0$ & $0.1 \pm 0$ & $0 \pm 0$ & $0.05 \pm 0.28$ \\
\hline
\end{tabular}

Data from bioassays of aphids collected from wheat and barley fields near Prosser, Washington State, showed that $R$. maidis reached high population densities only on late autumn barley (Halbert and Pike, 1985).

In studies on field populations of cereal aphids attacking small spring grains in South Dakota, Schizaphis graminum (Rond.), S. avenae and $R$. padi commonly attacked wheat, barley and oats, while $R$. maidis occurred only on barley (Kieckhefer, 1975). Infestation of barley with $R$. maidis occurred also in Magdeburg county, Germany (Dubnik and Thormeier, 1988). In the UK, 5 species of aphid commonly occurred on cereals between April and September. These species were R. padi, M. dirhodum, S. avenae, Sitobion fragariae (Wlk.) and M. festucae. R. maidis has been occasionally recorded on barley leaves (George and Plumb, 1982).

All information mentioned above supports the conclusion that in many countries, $R$. maidis, in spite of its name, develops much better on barley than on maize.

Several species of cereal aphids, including $R$. maidis, persist and reproduce parthenogenetically throughout the year in the southern areas of the USA. They persist less readily or not at all in the northern states and Canada where winters are cold and these areas are reinvaded annually by migrants from the south (Irwin and Thresh, 1988). Reports 
from the USA show that the first migrants of $R$. maidis were observed during the first half of June (Post and Olson, 1961; Robinson and Hsu, 1963). The summer and autumn flight activity of cereal aphids was monitored in South Dakota, by operating a large suction trap continuously from 1 June to mid-November. R. maidis occurred in early August and in mid-September (Kieckhefer and Lytle, 1976). In southwestern Ontario the largest emigration of alatae from the maize plants was found in August and from about mid-September to mid-October (Foot, 1977). A similar situation occurs in Europe, only the migration of insects is relatively more limited by mountains. Mountain edges in America are oriented in the direction south-north and mountain edges in Europe are oriented in the direction east-west. Migrating insects need a suitable host plant for their next reproduction in new areas. In Slovakia, spring cereals are already harvested in July and maize is past flowering at the end of July. Except for maize or young cereals from seeds dropped during the harvest, other possible host plants should be grasses. $R$. maidis did not fare well on any of 12 species of grasses tested (Stoner and Kieckhefer, 1979). But, $R$. maidis was found on spring barley, Echinochloa crus-galli (L.) Beauv., Festuca pratensis Huds., and winter barley in eastern Germany (Geissler and Karl, 1987). R. maidis overwinters in a milder climate and is regularly reintroduced to central Hungary where it occurred on Echinochloa cruss-galli (Basky and Eastop, 1995). Matured maize plants in late summer and in autumn are probably not very suitable hosts for any aphid except for $R$. padi which is known as a species well developing on the oldest plant leaves (Pons et al., 1989). In Slovakia, winter cereals are usually sown during September-October. During the same months, young plants of winter cereals are emerging. In October it is probably too late to develop a new population of $R$. maidis on these plantations. But, we should mention that the weather in September and at the beginning of October was much warmer then usually. So, it seems that in a regular situation, without the summer development of barley plants, there is a little chance for the development of a strong $R$. maidis population in Slovakia.

The demographic structure of aphid populations on barley during autumn is shown in Table 2. Larvae and nymphs formed the highest percentage of populations. Alate females formed $6.7 \%$ of $R$. maidis population but only $0.6 \%$ of $R$. padi population. A

\section{Table 2}

Demographic structure of aphid population on barley plants on October 13, 1999 (variety Sladko). Aphids were collected from 10 randomly chosen plants. Locality Nitra-Malanta. Altitude $230 \mathrm{~m}$

\begin{tabular}{|c|c|c|c|c|c|}
\hline & $\mathrm{n}$ & $\begin{array}{c}\text { Larvae } \\
\%(\mathrm{n})\end{array}$ & $\begin{array}{c}\text { Nymphs } \\
\%(\mathrm{n})\end{array}$ & $\begin{array}{c}\text { Alate females } \\
\%(\mathrm{n})\end{array}$ & $\begin{array}{c}\text { Apterous females } \\
\%(\mathrm{n})\end{array}$ \\
\hline Rhopalosiphum maidis & 1472 & $\begin{array}{l}52.6 \\
(774)\end{array}$ & $\begin{array}{l}38.2 \\
(562)\end{array}$ & $\begin{array}{l}6.7 \\
(99)\end{array}$ & $\begin{array}{r}2.5 \\
(37)\end{array}$ \\
\hline Rhopalosiphum padi & 342 & $\begin{array}{l}59.9 \\
(205)\end{array}$ & $\begin{array}{l}34.5 \\
(118)\end{array}$ & $\begin{array}{l}0.6 \\
(2)\end{array}$ & $\begin{array}{r}5.0 \\
(17)\end{array}$ \\
\hline Sitobion avenae & 59 & $\begin{array}{l}57.6 \\
(34)\end{array}$ & $\begin{array}{l}22.0 \\
(13)\end{array}$ & $\begin{array}{l}6.9 \\
(4)\end{array}$ & $\begin{array}{r}13.6 \\
(8)\end{array}$ \\
\hline Metopolophium dirhodum & 13 & $\begin{array}{l}69.2 \\
(9)\end{array}$ & $\begin{array}{l}30.8 \\
(4)\end{array}$ & $\begin{array}{l}0.0 \\
(0)\end{array}$ & $\begin{array}{l}0.0 \\
(0)\end{array}$ \\
\hline
\end{tabular}


higher number of apterous females occurred in the population of $R$. padi. Females accounted for more than $20 \%$ of individuals of the $S$. avenae population. The results suggest that $R$. padi is more adapted to colder temperatures in autumn than $R$. maidis. The $R$. padi population still did not produce high number of alate females in October. This is not very surprising because $R$. maidis is the aphid of warm areas, whereas $R$. padi is usual pest of cereals especially in the countries of northern Europe (Andersson, 1977; Chiverton, 1986).

A higher ratio between females and immature forms in the population of $S$. avenae should indicate that production of young larvae is smaller than it is in the population of the other two species. The conditions for the development of $S$. avenae were probably less suitable than for both Rhopalosiphum species. Similarly, when $R$. maidis and $R$. padi were fed on resistant maize varieties, an increase was observed in the migration of apterous and in the incidence of alatae (Vereshchagina and Gandrabur, 1988).

From 2116 aphids observed on 30 main tillers, 97 (4.58\%) and from 2283 aphids observed on 30 lateral tillers, 153 individuals $(6.70 \%)$ were infected by entomophthoralean fungi. From the sample of 95 infected aphids, 70 were infected by Entomophthora planchoniana Cornu and 24 were infected by Erynia neoaphidis Remaudière et Hennebert (= Entomophthora aphidis Hoffmann). Mixed infection caused by both entomophthoralean species was found in one case. It seems that the same fungus species infect the aphid in different climatic conditions. E. neoaphidis caused the infection of $R$. maidis in Israel (Kenneth and Olmert, 1975) or Canada (Remaudière et al., 1978), E. planchoniana in Israel (Kenneth and Olmert, 1975).

\section{Literature}

Andersson, K. (1977): Varfor fungerar inte bekampningen av bladloss i strasad? [Why does control of aphids on cereals not succeed?] Vaxtkyddsnotiser 41, 67-76.

Basky, Z. and Eastop, V. F. (1995): Diuraphis noxia and other cereal aphids in Hungary. J. Aphidology 5, 1-8.

Bremer, K. and Raatikainen, M. (1975): Cereal diseases transmitted or caused by aphids and leafhoppers in Turkey. Annales Academiae Scientiarum Fennicae, A, IV Biologica 203,14 pp.

Breniaux, D., Lescar, L. and Moreau, J. P. (1976): Les pucerons des cereales. Phytoma 28, 7-14

Chiverton, P. A. (1986): Predator density manipulation and its effect on population of Rhopalosiphum padi (Hom: Aphididae) in spring barley. Annals of Applied Biology 109, 49-60.

Darwish, Y. A. and Ali, A. M. (1991): Field population trends of cereal aphids and their natural enemies on corn plants in Upper Egypt. Assiut Journal of Agricultural Sciences 22, 33-42.

De-Gouveia, M. A. (1984): Contribuicao para o estudo dos afideos dos cereais em Portugal [Contribution to the study of cereal aphids in Portugal]. Boletim da Sociedade Portuguesa de Entomologia 56, 289-316.

Dubnik, H. and Thormeier, H. (1988): Ergebnisse der Beobachtungen des Massenwechsels der Blattlause auf Wintergerste im Herbst in den Jahren 1983 bis 1985 und Schlussfolgerungen für die Einschatzung der Bekampfungsnotwendigkeit. Nachrichtenblatt für den Pflanzenschutz in der DDR 42, 12-15.

Fereres, A., Ortego, F. and Castanera, P. (1990): Dinamica de las poblaciones invernantes de pulgones de cereales en la zona centro de la Peninsula Iberica [Population dynamics of overwintering cereal aphids on different host plants in the central region of the Iberian Peninsula]. Investigacion Agraria, Produccion y Proteccion Vegetales 5, 447-462.

Foot, W. H. (1977): Biology of the corn leaf aphid, Rhopalosiphum maidis (Homoptera: Aphididae), in southwestern Ontario. Can. Ent. 109, 1129-1135. 
George, K. S. and Plumb, R. T. (1982): Cereal aphids. Leaflet, Ministry of Agriculture, Fisheries and Food No. 586, p. 8.

Geissler, K. and Karl, E. (1987): Der Anteil der Maisblattlaus (Rhopalosiphum maidis (Fitch) an der Gesamtpopulation der Getreideaphiden im Raum Aschersleben im Jahre 1986 sowie ihre Bedeutung als Vektor des Gerstengelbverzwergungs Virus (barley yellow dwarf virus). Archiv für Phytopathologie und Pflanzenschutz 23, 415-416.

Grigorov, S. (1982): Interrelations between aphidophages and leaf aphids in cereal crops. Rasteniev'dni Nauki 19, 107-119.

Halbert, S. E. and Pike, K. S. (1985): Spread of barley yellow dwarf virus and relative importance of local aphid vectors in central Washington. Annals of Applied Biology 107, 387-395.

Hand, S. C. and Carrillo, J. R. (1982): Cereal aphids on maize in southern England. Annals of Applied Biology 100, 39-47.

Henry, M. and Dedryver, C. A. (1989): Fluctuations in cereal aphid populations on maize (Zea mays) in western France in relation to the epidemiology of barley yellow dwarf virus (BYDV). J. appl. Ent. 107, 401-410.

Irwin, M. E. and Thresh, J. M. (1988): Long-range aerial dispersal of cereal aphids as virus vectors in North America. Philosophical Transactions of the Royal Society of London. Series B, Biological Sciences $321,421-446$.

Kania, C. (1962): Szkodliwa entomofauna kukurudzy obserwowana w okolicach Wroclawia w latach 1956-1959 (cz. II.). Polskie Pismo Entomologiczne Seria B, 27-28, 183-216.

Kenneth, R. and Olmert, I. (1975): Entomopathogenic fungi and their hosts in Israel: Additions. Israel J. Entomology 10, 105-112.

Kieckhefer, R. W. (1975): Field populations of cereal aphids in South Dakota spring grains. Journal of Economic Entomology 68, 161-164.

Kieckhefer, R. W. and Lytle, W. F. (1976): Summer and autumn flight of cereal aphids in South Dakota. Journal of Economic Entomology 69, 421-422.

Knechtel, W. K. and Manolache, C. (1944): Neue Blattläuse für Rumänien. Acad. Roum. Bull. Sect. Scient. 26, $1-13$.

Manolache, C., Perju, T. and Felecan, V. (1968): Homoptere (Aphidoidea si Psylloidea) transmitatoare de boli virotice la culturile de cartof din Transilvania [Homoptera (Aphidoidea and Psylloidea) vectors of virus diseases in potato crops in Transylvania]. Analele Institutului de Cercetari pentru Protectia Plantelor 6, 329-336

Mészáros, Z., Ádám, L., Balázs, K., Benedek, I. M., Draskovits, Á. D., Kozár, F., Lövei, G., Mahunka, S., Meszleny, A. et al. (1984): Results of faunistical studies in Hungarian maize stands (Maize ecosystem research No. 16). Acta Phytopath. Academiae Sci. Hung. 19, 65-90.

Milinkó, Z., Rakk, V. and Kovács, G. (1983): Population dynamics of aphids, vectors of maize dwarf mosaic virus and aphid resistance of some maize hybrids. Acta Phytopath. Academiae Sci. Hung. 18, 201-208.

Müller, F. P. (1961): Blattläuse an Mais. Nachrichtenblatt Dtch. Pflanzenschutzdienst 15, 181-184.

Müller, F. P. and Freitag, G. (1960): Die Maisblattlaus erstmallig in Mitteleuropa. Dt. Landw. 12, 181-182.

Ossiannillson, F. (1959): Contributions to the knowledge of Swedish aphids. II. Kungl. Lantbrukshögskolans Annaler 25, 375-527.

Papierok. B. (1989): On the occurrence of Entomophthorales in Finland. I. Species attacking aphids (Homoptera, Aphididae). Ann. Entomol. Fennici 55, 63-69.

Pons, X., Comas, J. and Albajes, R. (1989): Maize aphids in the north-east of Spain. Acta Phytopath. ent. Hung. 24, 173-176.

Post, R. L. and Olson, G. H. (1961): The relative abundance and seasonal appearance of cereal aphids on barley and grasses. Proc. N. Cent. Br. Ent. Soc. Am. 16, 37-39.

Remaudière, G., Latgé, J. P. and Smirnoff, W. A. (1978): Considérations écologiques sur quelques Entomophthorales pathogenes d'aphides communes dans l'est des U.S.A. et du Canada. Phytoprotection 59, $150-156$. 
Robinson, A. G. and Hsu, S. J. (1963): Host plant records and biology of aphids on cereal grains and grasses in Manitoba (Homoptera: Aphididae). Can. Ent. 95, 134-137.

Štalmachová, M. and Cagáň, L. (1999): Entomophtorales as significant natural enemies of cereal aphids infecting maize in Slovakia. Proceedings of abstracts of the 7th European Meeting in the IOBC/WPRS, March 22-26, Vienna, Austria.

Stoner, W. N. and Kieckhefer, R. W. (1979): Survival and reproduction of four cereal aphids on certain range grasses. Environmental Entomology 8, 694-695.

Stroyan, H. L. G. (1955): Recent additions to the British aphid fauna. II. Trans. R. Ent. Soc. Lond. 106, $283-340$.

Vereshchagina, A. B. and Gandrabur, S. I. (1988): Behavioral reactions of cereal aphids fed on corn of varying resistance. Soviet Journal of Ecology 19, 98-101. 